\title{
Ines Ackermann
}

Wydziat "Artes Liberales”

Uniwersytet Warszawski

\section{POLSKA MŁODZIEŻ NA LITWIE: O PULAKACH I WILNIUKACH ${ }^{1}$}

Szukając w internecie informacji o Polakach mieszkających na Litwie, można znaleźć bardzo różne strony. Niektórzy internauci przypominają tak zwane polskie czasy, można więc trafić na mapy, piosenki czy stare zdjęcia z Kresów. Oprócz tego pojawiają się także aktualne dyskusje: o polskojęzycznych tabliczkach z nazwami ulic w miasteczku Ejszyszki (lit. Eišiškès) lub o maturze w polskojęzycznych szkołach. Można również poczytać o różnych zespołach i kołach, w których razem śpiewa się, tańczy i pielęgnuje polskie tradycje.

Wszystkie te działania służą zachowaniu polskiej tożsamości narodowej i tradycji, kultywowaniu języka polskiego. Istnieją również grupy, które interesuje problem żywotności własnego języka regionalnego. Na swoich stronach internetowych ich członkowie piszą, w jaki sposób mówią po polsku i jaka jest ich tożsamość. To właśnie internetowym wizerunkiem członków tych grup, przeważnie młodych ludzi, zajmę się w niniejszym artykule. Jego głównym tematem jest grupa Pulaki z Wilni, jej blog i strona na Facebooku. A ponieważ nawiązują oni do określenia Wilniuki, charakteryzując własną grupę, wyjaśnienie tej nazwy stworzy kontekst do przedstawienia Pulaków. Na końcu krótko wspomnę o dziś już mało znanej grupie tak zwanych vičów, którzy w latach 90., podobnie jak Pulaki, sformułowali swoją definicję polszczyzny i ustalili pisownię języka polskiego na Wileńszczyźnie.

\section{Wilniuki}

Wielu Polaków z Litwy do dzisiaj chętnie określa siebie jako Wilniuków. W przeprowadzonych przeze mnie wywiadach szczególnie młodsi informatorzy często używali tej nazwy. W 2009 roku w Wilnie odbył się I Światowy Zjazd Wilniuków². Strona internetowa zapraszająca na zjazd wygląda profesjonalnie, można z niej wywnioskować, że zjazd odbił

${ }^{1}$ Publikacja powstała w ramach programu Międzynarodowe Projekty Doktoranckie Fundacji na rzecz Nauki Polskiej, współfinansowanego przez Unię Europejską w ramach Europejskiego Funduszu Rozwoju Regionalnego.

${ }^{2}$ Por. strona zjazdu: http://www.wilniuki.lt/index.php/pl/home.html (31.7.2012). 
się wówczas szerokim echem medialnym i uzyskał pozytywne oceny jego uczestników. Na stronie widnieje też zapowiedź kolejnego spotkania, do którego jednak do tej pory nie doszło. Co ciekawe, strona podaje własną interpretację słowa Wilniuk:

Wilniuk - to dziecię Obojga Narodów. To wytwór państwa federacyjnego, złożonego z Korony Państwa Polskiego i Wielkiego Księstwa Litewskiego. [...] Prawdziwy Wilniuk wcale nie musi pochodzić z Wilna, ani tam aktualnie mieszkać. Wystarczy, że się wywodzi z okolic - z Wileńszczyzny (do dzisiaj rdzeń tego obszaru wyznacza trójkąt między Wilnem, Solecznikami i Trokami) $)^{3}$.

Autorzy strony podkreślają, że istnieje różnica pomiędzy pojęciem wilnianin, czyli mieszkaniec Wilna, a Wilniuk. Piszą, że „Wilniuk to los”, często związany z represjami lub wypędzeniami. Wilniuk ma korzenie na Wileńszczyźnie, a także pewne typowe cechy charakteru. Jak czytamy:

Wilniuk ma w sobie trochę białoruskiej pokory, nieco żydowskiej przezorności i skłonności do filozofowania, sporo litewskiej powściągliwości, która jednak niekiedy ustępuje rosyjskiej zadziorności.

Podobne rozumienie nazwy Wilniuk przedstawił 24-letni mężczyzna z Wilna biorący udział w badaniach ankietowych, które przeprowadziłam w 2008 roku. Z jego wypowiedzi wynika, że określając siebie jako Wilniuka, czuje się zwolniony z wyboru między Litwą a Polską jako ojczyzną:

Zazwyczaj, gdy pytają mnie, za kogo się uważam, Polaka czy Litwina, odpowiadam, że jestem Wilniukiem lub Polakiem z kraju Wileńskiego. Bo ani mój polski język nie ma poprawnego akcentu, „fizycznie” z Polską również prawie nic mnie nie łączy (żadnych przyjaciół, tylko dalsza rodzina). W żadnym wypadku nie mógłbym też nazwać Polskę ojczyzną. Młody Polak (nieinteligentny) powie, że jestem „ru ski”, młody Litwin (nieinteligentny) powie, że jestem Białor usin i kółko się zamyka. A w tym kółku kraj Wileński, Wileńszczyzna. I każdy kto dokładnie zbadał historię wie, że chociaż Wileńszczyzna leży w granicach współczesnej Litwy, jej dusza wcale nie jest Litewska. Od założenia Wilna zawsze było to miasto wielokulturowe.

I nie od wczoraj dominuje tu język polski ${ }^{4}$. Chociaż... trudno jest dzisiaj powiedzieć, że będzie tak dalej. Pomimo tego, że szkoły polskie są bardzo „silne” (stopa procentowa wstępowania na wyższe uczelnie wyższa niż w szkołach litewskich), pomimo aktywnego udziału w życiu kulturowym itd., władze Litewskie prowadzą politykę „łagodnej” Lituanizacji. Litwo - ojczyzno moja... Czasami, jak mnie pytają kim jestem, mówię - jak Mickie wicz. Typowy Wilniuk. Urodził się w Nowogródku (obecnie Białoruś), młode lata spędził w Wilnie (obecnie Litwa), a pisał, mówił, myślał po Polsku. I mówiąc „Litwa”, nie miał na myśli państwa, tylko kościoły, domy, ulice, łąki, pagórki, lasy... dęby, w których cieniu odpoczywali pradawni książęta Litewscy [wyróżnienia moje - I. A.].

${ }^{3}$ Ten i następne cytaty ze strony http://www.wilniuki.lt/index.php/pl/wilniuki/kim-sa-wilniuki. html (31.7.2012 r.).

${ }^{4} \mathrm{~W}$ przytoczonym fragmencie tej wypowiedzi chcę pokazać użycie określenia „Wilniuk”. Analiza pozostałych jej elementów, na przykład dotyczących „dominacji” języka polskiego w Wilnie czy poziomu szkół polskojęzycznych na Litwie, nie należy do tematu tego artykułu. 
Informatorzy często wymieniają wielokulturowość jako bardzo istotną cechę Wileńszczyzny. Jak wynika z wyżej cytowanego fragmentu, ale też z cytatów ze strony internetowej, ma to również wpływ na charakter Wilniuków. Autorzy strony zjazdu Wilniuków podkreślają, że mimo repatriacji (w nawiasie dopisano: „właściwie deportacji"s) i represji zachowali oni swoje tradycje, wiarę i język w czasach radzieckich. Wilniuki

to społeczność niezwykle przywiązana do swojej Ojczyzny Litwy, ale mająca świadomość przynależności do obu narodów - polskiego i litewskiego. Za swój język ojczysty ta społeczność uważa polski z tym, że dzisiejszy Wilniuk jest przeważnie (i to od dziecka) co najmniej trójjęzyczny. Mówi równie dobrze po polsku, litewsku, rosyjsku, niekiedy po białorusku. I żadnego z tych języków Wilniuk nie wpisze do rubryki ,języki obce”, bo wszystkie są po trosze... ojczyste, znane od dziecka ${ }^{6}$.

Takie samookreślenie Wilniuków jest wyraźnie zbieżne z tym, jak moi rozmówcy na Litwie mówią o sobie. Widać więc, kim chcą być: wielojęzyczni, otwarci i przyjaźni innym narodom, ale jednocześnie też świadomi i dumni ze swojej polskości. Tym tropem chcą iść również Pulaki $z$ Wilni.

Według informacji Haliny Karaś z internetowej poradni językowej PWN, liczba mnoga terminu Wilniuk może mieć formę bardziej literacką Wilniucy lub bardziej potoczną i nacechowaną stylistycznie - Wilniuki. Wilniuk to określenie gwarowe, stworzone przez dodanie regionalnego przyrostka $-u k$. W gwarach wileńskich nie istnieje kategoria męskoosobowości, dlatego też częściej spotyka się formę niemęskoosobową Wilniuki niż formę męskoosobową Wilniucy ${ }^{7}$.

\section{Pulaki z Wilni}

Również młodzi członkowie grupy Pulaki z Wilni odwołują się do określenia Wilniuki i tak samo używają formy niemęskoosobowej. Oryginalnie Pulaki byli (albo raczej: były) fanami bloga internetowego dziewczyny ${ }^{8}$, która postanowiła pisać językiem Polaków na Wileńszczyźnie. Blog przekształciła w grupę na Facebooku mającą dziś ponad 2600 fanów (stan z grudnia 2012 roku). Blog istnieje od sierpnia 2009 roku, od marca 2011 roku grupa funkcjonuje także na Facebooku. Na blogu http://pulakizwilni.blogspot. de/ znajdują się krótkie teksty, słowniczek „,wileńsko”-polski i zbiór fraz „po wileńsku” z tłumaczeniem ogólnopolskim. Można znaleźć karykatury, zdjęcia i filmiki, powstał nawet dedykowany kanał na YouTube'. Autorka bloga pisze:

${ }^{5}$ http://www.wilniuki.lt/index.php/pl/wilniuki/kim-sa-wilniuki.html (31.07.2012).

${ }^{6}$ http://www.wilniuki.lt/index.php/pl/wilniuki/wilniuki-dzis.html (31.07.2012).

7 Por. http://poradnia.pwn.pl/lista.php?id=10310 (31.07.2012).

${ }^{8}$ Ewelina Mokrzecka, autorka bloga, występuje przeważnie anonimowo. Pulaki stały się jednak na tyle znane, że w mediach cytuje się już często pełne nazwisko założycielki bloga, por. http://pl.delfi.lt/ kultura/kultura/pulaki-z-wilni-swoim-jezykiem-do-swoich-ludzi.d?id=57900252 (17.12.2012).

${ }_{9}$ Por. http://www.youtube.com/user/pulakizwilni (20.08.2012). 
Na puczontek puwiem, czemu cościk takiego powstało, jak ten blog. Tak co wot: na Wileńszczyźnie mami swoje gaziety, taki jak Kurier Wileński, Wileńszczyzna itd. Ale nima u nas czeguścik takiegu, żeb Wilniuk czytałby po swojemu, w tzw. jenzyku wileńskim. Bądź co bądź jenzyk wileński jest jedyny w swoim rodzaju i musim jegu pilengnować, tak jak język mówiony pilengnuje nasz szanowny Wincuk z Pustaszyszek. Tak co kochanińkie, ta strona bendzi poświęcona nam - Wilniukom! Pujichali! ${ }^{10}$

Język pisany jest tu ważnym, może nawet najważniejszym elementem: prawie wszystkie teksty są pisane „po wileńsku”, toczą się dyskusje na temat tego, jak ludzie mówią na Wileńszczyźnie. Autorka podkreśla ponadto, że przedstawia „codzienność mieszkających tu [na Wileńszczyźnie - I. A.] Polaków w sposób żartobliwy, trochę w krzywym zwierciadle" ${ }^{11}$. Pisząc językiem „niskim”, regionalnym, Pulaki manifestują swoją odmienność od Polaków (z Polski) i jednocześnie nobilitują „język wileński”. Jest to gra, która może pokazać dużo prawdy o swoich twórcach - że doceniają mieszankę kulturową, ale również językową na Wileńszczyźnie.

Autorka strony pochodzi z Wileńszczyzny, ale obecnie mieszka w Warszawie. To ona stworzyła bloga i stronę, jednak, zwłaszcza na Facebooku, komentarz może zostawić każdy użytkownik, toteż o większości autorów nic nie wiemy. Jedną z cech Facebooka jest to, że można tam wykreować własny obraz, można prezentować się w dowolny sposób, a więc przyglądanie się profilom komentujących użytkowników nie dostarczyłoby zbyt wielu informacji - nie można być pewnym, które umieszczone tam dane (np. rok urodzenia) są prawdziwe. Według badań statystycznych wiemy jednak, że na Litwie ponad połowa użytkowników tej platformy to osoby między 18. a 34. rokiem życia ${ }^{12}$.

W listopadzie 2012 roku autorka strony, Ewelina Mokrzecka, została kandydatką do tytułu „Polaka roku 2012” w plebiscycie „Kuriera Wileńskiego”, polskiego dziennika na Litwie. Wybrano 18 osób, na które czytelnicy mogli głosować do 31 grudnia 2012 roku $^{13}$. Na Facebooku autorka podkreślała, że to „ni nominacja dla admina, to nominacja dla wszystkich fanów PzW! Kto jak kto, ale to fany tworzo ta stroniczka!"14.

Pisanie „po wileńsku” jest dla autorów zabawą. Jak widać z przytoczonych wyżej cytatów, piszą tak celowo i konsekwentnie (we wszystkich komentarzach na stronie). Błędy językowe w większości przypadków nie wynikają z tego, że nie potrafią poprawnie posługiwać się językiem. Jest to zabieg świadomy, chcą oni, często przesadzając, oddać specyfikę języka mówionego w jego najbardziej regionalnym wariancie. Z mojego doświadczenia wynika, że osoby, które uważają się za Polaków,

${ }^{10} \mathrm{http}: / /$ www.facebook.com/pulakiziwlni/info (15.08.2012).

11 Tamże.

12 Por. http://www.socialbakers.com/facebook-statistics/lithuania (30.12.2012).

${ }_{13}$ Por. http://kurierwilenski.lt/2012/11/07/wytypowano-kandydatow-do-tytulu-polak-roku-2012/ (17.12.2012).

14 http://www.facebook.com/events/557645104252952/ (27.12.2012). 
ale chodziły do litewsko- lub rosyjskojęzycznych szkół, potrafią mówić po polsku, lecz nie umieją, a nawet nie próbują pisać w tym języku. Takie osoby znalazły się wśród moich respondentów; zawsze pisały po angielsku, mimo że rozmawiały ze mną wyłącznie po polsku. Zakładam więc, że autorzy przedstawionych tutaj wypowiedzi chodzili do polskojęzycznych szkół na Litwie. Można też przyjąć, że raczej nie są oni językoznawcami, wobec czego ich wypowiedzi oddają to, w jaki sposób sami mówią i co słyszą. To zjawisko odbiło się szerokim echem wśród użytkowników Facebooka, także wśród mediów.

Kilku moich młodszych rozmówców z Wilna i okolic (w wieku 17-25lat) zwróciło mi uwagę na stronę na Facebooku, mówiąc, że mogę tam dowiedzieć się wszystkiego o nich i o ich języku, badania terenowe nie będą więc mi już potrzebne. $Z$ tej wypowiedzi wynika, jak wysoko cenią sobie autentyczność tej strony - mimo że porównanie języka mówionego respondentów z językiem strony szybko pokazuje, że ten używany na Facebooku jest przesadnie nasycony cechami regionalnymi.

Respondenci piszą w języku „wileńskim” także maile i sms-y. Powstaje więc nowa moda: pisana odmiana regionalnego języka polskiego, która ponad miarę nasycona jest regionalizmami i rusycyzmami, w o wiele większym stopniu, niż zdarza się to w języku codziennym. Co do klasyfikacji „języka wileńskiego Facebooka” doszło już $\mathrm{w}$ internecie do niejednego sporu - czy jest on mieszanką językową, gwarą, czy też wynikiem braku znajomości poprawnej polszczyzny. Dla mnie interesujący jest przede wszystkim fakt, że młodzi ludzie chcą zapisać swój język w taki sposób, w jaki go używają. W przytoczonych poniżej cytatach można spotkać bardzo wiele elementów rosyjskich, regionalnych albo też spontanicznie wymyślonych, co oznacza, że prawdopodobnie żaden $\mathrm{z}$ autorów nie posługuje się takim językiem naprawdę. Również z ich dyskusji wynika, że starają się znaleźć jak największą liczbę elementów różniących go od języka ogólnopolskiego. Nie należy więc traktować tego języka jako przykładu nowej gwary wileńskiej, lecz raczej jako grę, podobającą się zwłaszcza młodym ludziom. Jeden z moich rozmówców po naszym spotkaniu napisał do mnie maila:

[...] Siostra i kolega mowili ze nibedo mieli czasu na spotkania. [...] Tu najdziesz informacje o muzeum etnograficznym wilenszczyzny w niemenczynie. [...] Tutaj najdziesz autobusy ktore jado do niemeneczyna [mężczyzna, 24 lata, pochodzi z Niemenczyna (lit. Nemenčinè) na Wileńszczyźnie, obecnie studiuje w Wilnie; określa się jako Polak; lipiec 2012].

Używany w mailu czasownik najdować (w tekście dwa razy najdziesz) jest polskim archaizmem i znaczy 'znajdywać, por. [Rieger, Rutkowska, Masojć 2006: 237], a formy jado i nibedo skłaniają do interpretacji, że informator pisze końcówki tak, jak je słyszy i jak je wymawia, czyli odnosowione. A ponieważ ukończył polskojęzyczną szkołę, można założyć, że wie, jakie są końcówki czasowników w czasie teraźniejszym. Trzeba również pamiętać, że w wiadomości mailowej brakuje polskich znaków diakrytycznych i nie ma wielkich liter. Prawdopodobnie respondent pisał więc tak, jak zazwyczaj pisuje do swoich kolegów, nie wkładał wysiłku w używanie poprawnej polszczyzny. Prawie nigdy nie ma w tych tekstach polskich znaków diakrytycznych, 
wobec czego czytelnik musi się domyślić, gdzie brakuje ich celowo, a gdzie wynika to z pomijania ich przy pisaniu na komputerze.

Również u innych młodszych Polaków z Litwy można zauważyć bądź na Facebooku, bądź w sms-ach czy mailach, że korespondują ze sobą polszczyzną regionalną, czasami też językiem mieszanym - przy użyciu kreatywnej pisowni, która częściowo powstaje spontanicznie, częściowo już się utrwaliła. Tak wygląda również „język wileński” używany na blogu Pulaków i na ich stronie na Facebooku. Już samo logo grupy ma, rzecz jasna, napis „po wileńsku”:

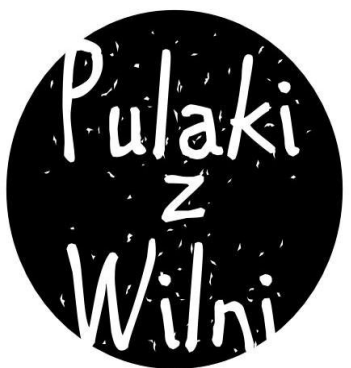

tu gadasia po wilenskeu

Il. 1. Logo Pulaków na Facebooku ${ }^{15}$ (Autorką wszystkich zdjęć jest Ewelina Mokrzecka)

Na stronie widać, że Pulaki zaczynają działać dość profesjonalnie. Można kupić kubki z napisem $w$ ich języku (por. il. 2), zwolennicy strony rozdają naklejki z napisem „Pulaki z Wilni” i adresem bloga. Mała grupa Pulaków pojechała na festiwal Przystanek Woodstock z wielką flagą ze swoim logo.

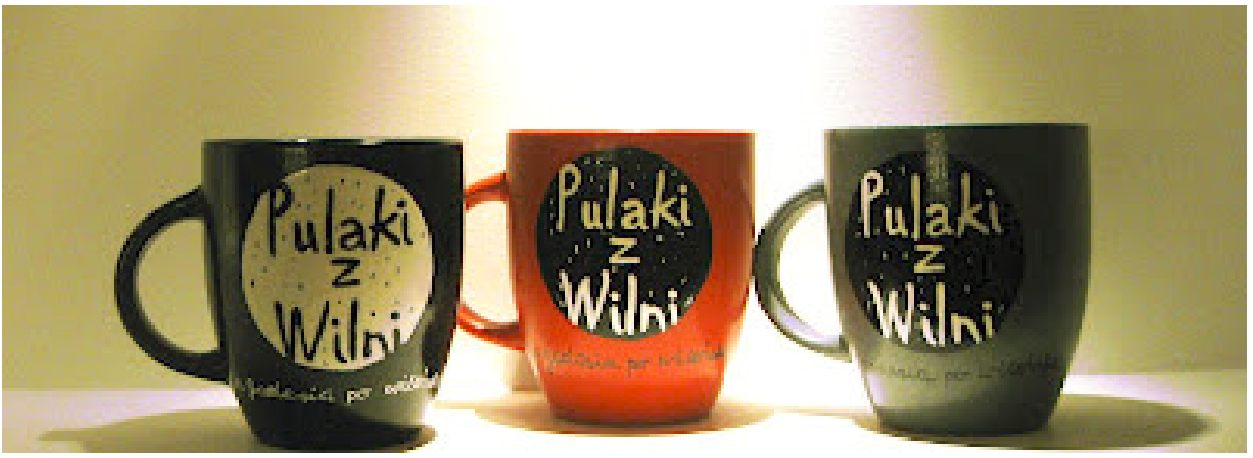

Il. 2. Kubki Pulaków ${ }^{16}$

15 http://sphotos-g.ak.fbcdn.net/hphotos-ak-ash4/431222_314548435272449_2073608376_n. jpg?dl=1 (27.12.2012).

${ }^{16} \mathrm{http} / / / 2 . b p \cdot$ blogspot.com/-HeTwblJWx6k/Tzly8Kx64DI/AAAAAAAABJ8/qhbGz1zR3AI/s400/ IMG_2656.JPG (30.12.2012). 


\section{Język Pulaków}

Na facebookowej stronie Pulaków użytkownicy przytaczają wypowiedzi, które ich zdaniem są wyjątkowo śmieszne i najlepiej ukazują język i życie Pulaków. W albumie „Z cyklu My Pulaki z Wilni, bo...” aktualnie znajduje się 188 obrazów ${ }^{17}$. Są one prezentowane $\mathrm{w}$ formie logo. Wszystkie mają ten sam layout, ale różny tekst. Przedstawiam tutaj niektóre z nich wraz z dyskusjami, które się wokół nich toczyły. Użytkownicy Facebooka spierają się, czy zdanie na obrazku jest typowe dla języka Polaków na Wileńszczyźnie, analizują pochodzenie poszczególnych cech językowych, przedstawiają dodatkową leksykę i proponują inne sformułowania.

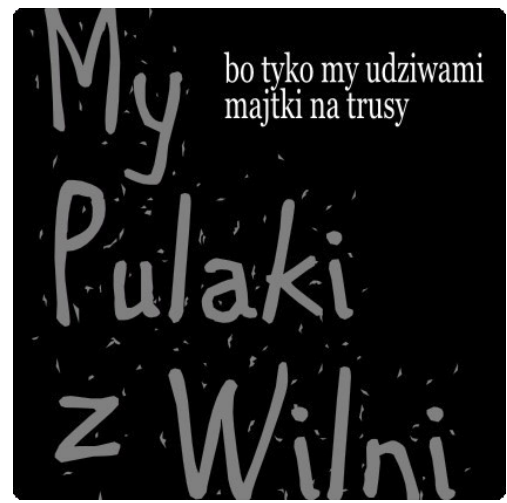

Il. 3. My Pulaki z Wilni - bo tylko my udziwami majtki na trusy ${ }^{18}$

Występują tu specyficzne wyrazy majtki i trusy. Trusy to wyraz rosyjski / białoruski, oznacza polskie 'majtki'. O wyrazie majtki w Słownictwie polszczyzny gwarowej na Litwie [Rieger, Rutkowska, Masojć 2006] czytamy, że to 'spodnie męskie', z gwary białoruskiej маŭmкi. Słownik wileński [Słownik języka polskiego 1861] podaje, że majtki to 'wierzchni ubiór męski na niższą część ciała’.

Pod obrazkiem znajduje się następująca dyskusja (skrócona wersja):

E. kiedys ktos z solecznickich stron podpowiedzial, ze pulaki z tamtad nadtoz kochaja polski jezyk i staraja sie mowic czysto po polsku... ! Np. 'sok apilsinkowy', 'sok tomatowy', 'kisteczka'. Kto moze jeszcze cos powiedziec ze my nie pilingnujim polskiego jezyka!! :)

J. e., ty zapomniala jeszcze chaj, pirog i piczenia :D

E. dobra dobra, idz pusmaruj warenja na piczenja !! :)

J. ja na rubocia, ni mam jak:)

O. ni kisteczka, a kIstaczka :D pujść w magazYn, kupić batOn, łabdara, itd itp. :)

${ }_{17} \operatorname{Stan}$ 27.12.2012, por. http://www.facebook.com/pulakiziwlni/photos_albums.

${ }_{18} \mathrm{http} / / /$ sphotos-a.ak.fbcdn.net/hphotos-ak-ash4/419312_313251748735451_1683881484_n.jpg (7.10.2012) 
E. nie, kIstaczka to po rosyjsku, a kistEczka - ladnie po polsku:)

D. A na łabdarach lachmany kupuicie? :D

M. Po prawdziwemu wileńsku było 'trąsy'. Trusy to zruszczona wersja.

O. E., ja nu niwiem, to moży od klasy zawisi. Bo ja pamientam jak na lekcjach plastyki - daj mnie druga kIstaczka, bo ta za cienka:) albo - idź pomyj kIstaczaka, bo brudna :)

D. a niektore jeszcze na trusy kalisony odziewają :)

K. Tyko my w zimie na ulica wychodzim z goło głowo : $\mathrm{D}^{19}$

Warto przyjrzeć się zarówno samej dyskusji, jak i jej językowi.

Używa się w niej wielu wyrazów z języka rosyjskiego, ale, co ciekawe, często $\mathrm{w}$ wersji spolszczonej, np. sok tomatowy (pewnie z akcentem na przedostatniej sylabie), pojawia się również nieistniejąca w polszczyźnie forma trąsy. Warto zwrócić uwagę na wyjaśnienie komentatora M., że jego zdaniem trusy to zruszczona wersja wileńskiego (!) słowa. Prawdopodobnie autor tego komentarza doskonale zdaje sobie sprawę, że mpyc $\underline{\text { bl }}$ to rosyjski / białoruski wyraz oznaczający 'majtki', jego wypowiedź półżartem oddaje wyobrażoną argumentację innych Pulaków. Podobnie jest z pusmaruj warenia na piczenja: piczenie znaczy tutaj 'ciasteczka, herbatniki' (por. ros. nеченьe). Poza tym autor używa formy warenja zamiast warenie, $\mathrm{z}$ regionalnym wygłosowym $a$.

We fragmencie my $w$ zimie na ulica wychodzim autor używa formy mianownika zamiast biernika (na ulica). Jest to osobliwość regionalna, według Zofii Kurzowej notowana już od XVII wieku, por. [Kurzowa 1993: 395-396]. Halina Turska [1948] uważa, że mamy tu do czynienia ze zmorfologizowaną cechą fonetyczną, która powstała między innymi pod wpływem akania (e zmienia się w nieakcentowanej pozycji w a). W niektórych przypadkach komentatorzy nie używają końcówek osobowych (ty zapomniala, my nie pilingnujim). Piszą, jak mówią: tak samo jak w logo (por. udziwami), w dyskusji kilka razy pojawia się tak zwane ukanie (pusmaruj, rubocia), tak więc $o$ przeszło w $\mathcal{u}$. Jest to zjawisko charakterystyczne dla gwar litewskich, notowane także w gwarach polskich na Litwie, por. [Rieger, Rutkowska, Masojć 2006: 24]. Oprócz tego autorzy często w ortografii oddają wymowę liter ę czy ą, pisząc np. pamientam, z goło głowo. Czasami w pisowni mieszają się różne systemy językowe, np. w wyrazie chaj jest to transkrypcja rosyjskiego yaŭ 'herbata', ale nie w pisowni polskiej, lecz angielskiej (niekonsekwentnej, por. końcowe j).

Często zdarzają się dyskusje, czy niektóre słowa są „prawdziwe wileńskie”, czy są

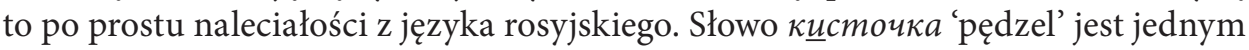
z takich przykładów. Jeżeli akcent pada na przedostatnią sylabę (kistoczka), wydaje się, że dla użytkowników słowo to brzmi bardziej po polsku. W wersji kịstaczka, $\mathrm{z}$ akcentem tak jak w języku rosyjskim, dochodzi jeszcze akanie. Widać tu jednak dobrze, że Pulaki śmieją się sami z siebie - autorka komentarza o regionalnej postaci kisteczka podkreśla ironię własnego sformułowania „ładnie po polsku” za pomocą smiley. W następnym fragmencie daj mnie druga kIstaczka znów notujemy regionalną

19 Fragmenty komentarzy do zdjęć z http://www.facebook.com/photo.php?fbid=313251748735451 $\&$ set=a.304606502933309.72788.156276621099632\&type $=1 \&$ theater $(7.10 .2012)$. 
postać biernika równą mianownikowi, ale też wyraz druga pewnie nie znaczy tutaj

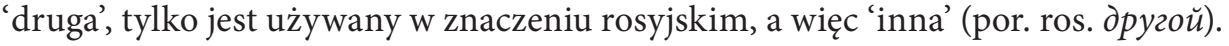

Wyrazu łabdara nie znalazłam w słownikach dotyczących słownictwa na Wileńszczyźnie, ale respondentka z Wilna zapewniła mnie, że tamtejsi ludzie nazywają w ten sposób to, co w Polsce określa się jako 'szmateks' albo 'ciucholand', czyli miejsce, gdzie można kupić używaną odzież. Wyraz labdara po litewsku oznacza 'dobroczynność. Mirosław Dawlewicz [2000] zaś podaje, że łabdara znaczy 'cudze papierosy, wyproszone od kogoś'.

Następny obrazek wywołał dyskusję na temat różnych nazw chleba.

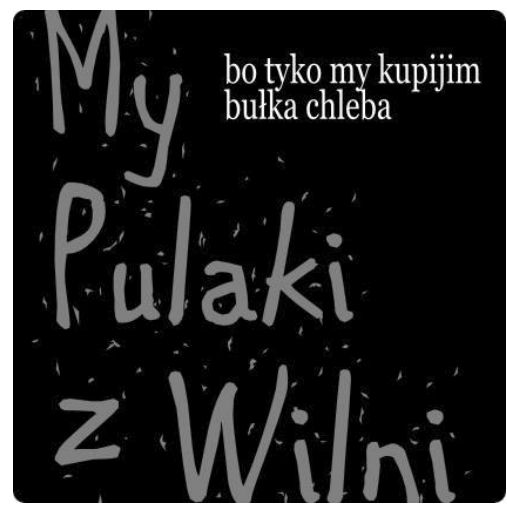

Il. 4. Bo tyko my kupijim bułka chleba ${ }^{20}$

D. nizapominajmy ob batonie. $w$ PL powiedzial, ze u nas kupujim baton, a mnie w odpowiedz: 'baton? co to? Guzik?'

Pulaki z Wilni baton to czykuladka :)

R. I tylko u nas jest cukiermi smaktulki :D

R. ktore my smokczym :)

D. nu widocznie splontali z 'button' od angielskiego :D

Ł. Ja to buchanka chleba kupuja xDD

A. Ja też buchanka ;) Przy czym pytanie 'buchniom?' wcale nie znaczy 'czy zjemy chleba?' :D

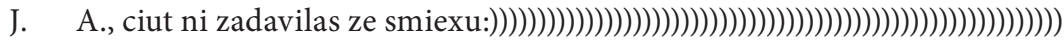

R. Tylko my jedne drugich zrozumiec mozym;)

R. Oczywiscie ze buchanka! Nigdy o bułce chleba nie słychawszy! Już tam warszawskim wam żelannoje za nastojaszcze nachodzi ;-)

B. R., mowio u nas tak bulka chleba, sama slyszala:)

O. a u nas w domu buchanka chlebu jeszcza dzielisia na łusty : )

P. o! nowa ciema :) łusty :)

B. u nas to skiby:) 


\section{Pulaki z Wilni aha, skiby słyszawszy :) a łusty, to jak łasty :) \\ J. polaki z polski muvio zdajsie pajdy ${ }^{21}$.}

Głównym tematem jest tu używana leksyka: baton pochodzi z rosyjskiego батон 'bułka, bagietka'. Ktoś skojarzył ten wyraz z batonikiem czekoladowym, a ktoś inny $\mathrm{z}$ angielskim button 'guzik'. Określenie z logo bułka chleba jest w Polsce znane na Białostocczyźnie ${ }^{22}$. Słownik wileński [Słownik języka polskiego 1861] podaje, że bułka to 'chleb okrągły lub podługowaty niewielki', Zofia Kurzowa [1993] notuje, że bułka to 'bochenek'. Użytkownik O. pod koniec dyskusji proponuje wyraz łusty. W Słownictwie polszczyzny gwarowej na Litwie [Rieger, Rutkowska, Masojć 2006] czytamy, że łusta znaczy 'kromka (chleba)'. Wyraz ten pochodzi z gwary białoruskiej rycma. Słownik Karłowicza [Koniusz 2001] oprócz łusty notuje również łusteczka 'krajanka, skiba, np. chleba'.

W środkowej części dyskusji pojawia się kilka wyrażeń z języka rosyjskiego (częściowo młodzieżowego), jak buchniom, z rosyjskiego бyxams 'upić się', ob batonie zamiast polskiego 'o batonie' i zadavilas od давиться 'dusić się'.

Oprócz cech, które już zostały omówione przy analizie pierwszej dyskusji, dwa razy znajdujemy tu znaną w polszczyźnie północnokresowej formę imiesłowu przeszłego czynnego na -wszy w funkcji orzeczenia czas przeszłego, por. (ja) słychawszy i (ja) słyszawszy. Forma słychawszy pochodzi prawdopodobnie od rosyjskiego czasownika сльххать 'słyszeć, mieć informację zasłyszaną od kogoś'.

W cytowanym fragmencie ciekawa jest również pisownia: kilka razy występuje litera $v$, pewnie w nawiązaniu do transliteracji z języka rosyjskiego, por. zadavilas, muvio. W ze smiexu autorka używa rosyjskiej litery $x$ zamiast polskiego $c h$. Taka mieszanka różnych systemów językowych jest również praktyczna przy pisaniu sms-ów - dzięki użyciu $x$ zamiast ch oszczędza się jedną literę.

\section{Być Polakiem na Litwie}

W tekstach Pulaków można przeczytać, że czują się spadkobiercami Wielkiego Księstwa Litewskiego. Pulaki często interesują się tematami związanymi z Wileńszczyzną, a w tym, co piszą, wyraźnie widać silną przynależność lokalną. Przykładem jest ogłoszenie konkursu pisania krótkich tekstów pod tytułem „Czemu Wileńszczyzna to najlepsza miejsca na świecie?"23.

Autorka bloga często podkreśla, że Pulaki z Wilni są apolityczni:

21 Fragmenty komentarzy do zdjęć z http://www.facebook.com/photo.php?fbid=315759068484719 \&set=pb.156276621099632.-2207520000.1356609950\&type=3\&src=http\%3A\%2F\%2Fsphotos-h.ak.fbcdn. net\%2Fhphotos-ak-ash4\%2F422445_315759068484719_1562358593_n.jpg\&size=420\%2C420 (7.10.2012).

22 Por. np. „plebiscyt” to najbardziej białostockie słowo lub określenie, http://bialystok.gazeta.pl/ bialystok/1,78942,9377252,Sie_mowi_sie___slownik_mowy_bialostoczan__Plebiscyt.html (26.12.2012).

${ }^{23}$ Por. http://pulakizwilni.blogspot.de/2012/01/czemu-wilenszczyzna-to-najlepsza.html (27.12.2012). 
To, co nas łączy, to przede wszystkim dystans do nas samych, a także do toczącego się konfliktu polsko-litewskiego. [...] Wierzę, że tylko poprzez kulturę, sztukę, zdystansowany dowcip można przynajmniej się starać zatrzymać ten konflikt ${ }^{24}$.

Na stronie internetowej Wilniuków można również przeczytać:

Dzisiejszych Wilniuków od tych przedwojennych różni przede wszystkim to, że mieszkają w innym państwie - w Republice Litewskiej. Ale jest to ich pańswto [sic!]. Utożsamiają się z nim i są wobec niego lojalni. Są świetnie zintegrowani ze społecznością litewską, zresztą stanowią jej cząstkę. [...] Jednak przy tym wszystkim Wilniuki mają świadomość swojego „wilniukstwa”, pewnej ukształtowanej na pograniczu kilku kultur odmienności - językowej, obyczajowej, kulturalnej i nawet mentalnej. Taka odmienność nie przeszkadza jedności tylko ją ubogaca ${ }^{25}$.

Tak samo uważają Pulaki, podkreślając: „Bo nikt nigdy ni moży zruzumieć, czemu bendonc Pulakami choruim za litewskie baskitbolne kamandy"26.

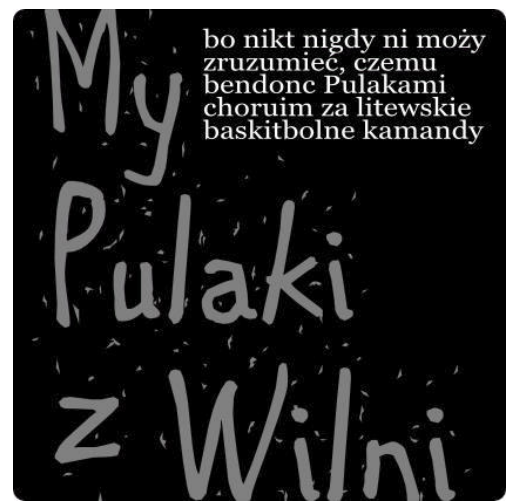

Il. 5 .

Kiedy autorzy tego obrazka choruja za kamandy, to znaczy, że kibicują - jest to kalka semantyczna z języka rosyjskiego болеть за кого. Dla nich to naturalne, że można bez problemu kibicować litewskiej drużynie koszykówki (a ta dyscyplina sportu ma wielkie znaczenie na Litwie!) i jednocześnie czuć się Polakiem. Od razu jednak widać, że tę solidarność z dwoma krajami nie wszyscy w Polsce rozumieją. W komentarzach internauci znów podejmują dyskusję na tematy językowe, a także w kwestiach lojalności:

P. Tak chorujcie za polskie kamandy, w czym prablemy? :)

A. Tak mu churuim za litewskie i nie ma tut żadnej prabliemy;)

${ }^{24}$ http://pulakizwilni.blogspot.de/?view=classic (5.03.2012), Siedź cicho!

25 http://www.wilniuki.lt/index.php/pl/wilniuki/wilniuki-dzis.html (31.07.2012).

26 http://sphotos-b.ak.fbcdn.net/hphotos-ak-snc7/432333_302858793108080_186100495_n.jpg (7.10.2012). 
J. o swieta prawda!

K. Bo w tych kamandach jest i Polakow:)

J. a za jakie polskie bolet'? :))

S. A jakie one litewskie, one 'tutejsze' :).

M. A ja to zauwazywszy, ze Pulaki z Wilna czensto umiejo nurmalnie grac i w basketbol i v futbol, i chorujo za te dwa klasne sporty:)

Ł. najcinzej to wytlumaczyc Polakom czemu my Pulaki tak robim... Nu nijak nirozumiejo ;D

A. Pochodzę z Wileńszczyzny i nigdy nie słyszałem słowa 'chorować' w kontekście 'ja choruja za kamanda'. 'Bolet" jak najbardziej²7.

W komentarzu użytkownika Ł. pojawia się rozróżnienie między Polakami, a więc mieszkańcami Polski, a Pulakami - Polakami mieszkającymi na Litwie. S. wprowadza do dyskusji określenie „tutejsze” (w formie niemęskoosobowej!), co rozwiązuje kwestię, czy gracze drużyny litewskiej są Litwinami czy Polakami - pochodzą z tych samych terenów jak Pulaki, nie są więc obcymi.

Jeśli chodzi o sprawy językowe, oprócz już wymienionych zjawisk w zdaniu Nie ma tut $\dot{z} a d n e j$ prabliemy spotykamy formę żeńską z akaniem i użyciem litery $i$ wskazującej na regionalną miękką artykulację spółgłoski l. Można więc uznać wyraz prabliema za rusycyzm, tak samo jak klasne (w znaczeniu 'wspaniałe') sporty, kamandy ('drużyny') i tut ('tutaj'). Raz występuje jest w liczbie pojedynczej tam, gdzie w języku ogólnopolskim występowałaby liczba mnoga: Bo w tych kamandach jest $i$ Polakow. To samo odnotowała już Halina Turska w języku polskim na Wileńszczyźnie, por. [Turska 1983: 22], tak jest również w języku rosyjskim. Podobnie jak i w rosyjskim, w dyskusjach Pulaków brakuje czasami łącznika być, np. A jakie one litewskie, one "tutejsze”.

\section{Towažystvo vičuv litevskich}

Już w latach 90. - wtedy jeszcze bez pomocy internetu - powstał pomysł nowego określenia języka polskiego na Wileńszczyźnie: język vičów, który zrodził się wśród członków Towažystva vičuv litewskich (jego nazwa nawiązuje do nazwisk kończących się na -wicz). Towažystvo vičuv litevskich nie jest już zbyt dobrze znane, czasami jednak pojawia się w dyskusjach o Polakach na Wileńszczyźnie. Warto podkreślić, że w przeciwieństwie do Pulaków Towažystvo vičuv litevskich uważało autochtoniczną ludność słowiańską na Litwie za osoby pochodzenia litewskiego, por. [Duličenko 2002: 559]. Była to mała grupa, której członkowie twierdzili, że polskojęzyczni mieszkańcy Litwy nie są Polakami, lecz Litwinami. Ich cel był więc dokładnie przeciwny niż Pulaków, chcieli podkreślić litewskość polskojęzycznych mieszkańców Wileńszczyzny, nie zaś

27 http://www.facebook.com/photo.php?fbid=302858793108080\&set=a.304606502933309.72788. $156276621099632 \&$ type $=1 \&$ theater (7.10.2012 r.). 
ich polskość. A lokalny język literacki, który nazwali vičsch ${ }^{28}$, miał być utworzony na podstawie lokalnego dialektu języka polskiego (tzw. prostego). Na przykład początek Pana Tadeusza w języku vičów brzmi następująco: „Litva! Ujčyzna moja! ty jestaš jak zdrowia" [Duličenko 2002: 560]. Być może w języku vičów widać podobieństwa do języka Pulaków, ale powody, dla których powstały te dwie grupy, są jednak bardzo różne.

\section{Podsumowanie}

Strona Pulaki z Wilni pokazuje wielką siłę internetu: nie potrzebujemy już oficjalnych towarzystw, żeby tworzyć liczną grupę, zbierać wspólne pomysły i razem dyskutować. Na blogu i na Facebooku można znaleźć o wiele więcej materiału, który mógłby potwierdzić moje tezy. Na platformach, takich jak Facebook, lub na blogach internetowych powstaje tak ogromna liczba tekstów, że właśnie tam trzeba szukać „perełek” językowych. Jest to oczywiście zupełnie inne źródło niż na przykład nagrane wywiady, ponieważ często brakuje kontekstu, każdy może pisać pod dowolnym pseudonimem, bardzo mało wiemy też o tym, dlaczego ktoś przedstawia konkretne argumenty. Istotnym elementem aktywności na takich stronach jest więc kreowanie własnego wizerunku przez użytkowników, co też czynią Pulaki. Strona pokazuje, w jaki sposób oceniają sami siebie, jakimi tematami się interesują i co ich bawi. Świadomie tworzą specyficzny język, używają go celowo, poddają go refleksji innych użytkowników.

Strona Pulaków jest ciekawym źródłem wiedzy na temat języka ludności Wileńszczyzny, a zwłaszcza tamtejszej młodzieży. Użytkownicy strony starają się oddać wszystkie te elementy językowe, które w rozmowie pojawiają się zazwyczaj dopiero w nieformalnych, bardziej swobodnych sytuacjach, kiedy oficjalne nagranie już się skończyło. A nawet więcej, na Facebooku można bowiem odnotować nagromadzenie tych form. Można się nimi bawić: wspólnie śmiać się i cieszyć z własnego sposobu mówienia. Znajdziemy więc tam spolszczenia rosyjskich słów i próby obrony języka polskiego przed naleciałościami rosyjskimi. W warstwie leksyki obok wielu wyrazów rosyjskich spotyka się też nieliczne litewskie. Użytkownicy dodają polską morfonologię, akcent i pisownię do zapożyczeń (np. kistęczka). Jeżeli rosyjskie słowa nie mają odpowiednika polskiego, wymyślają polską wersję (np. trasy) - również i tu można mówić o obronie polszczyzny, nie bez ironii. Kilka razy występuje na stronie tak charakterystyczny dla Wileńszczyzny regionalizm, jak imiesłów przysłówkowy uprzedni na $-(w) s z y$. Z nadmiernego użycia tych form można wnioskować, że Pulaki do dziś uważają je za typowo regionalne. W języku

${ }^{28}$ Miały powstać także inne lokalne języki literackie, np. halšanski jazyk i kul’n’adzka gavenda na bazie białoruskiej prosty mowy, a także dziukski na bazie dialektu litewskiego; por. [Duličenko 2002: 559-560] i [Nagórko 2000: 293]. 
pisanym pojawiają się także takie cechy fonetyczne, jak odnosowienia, prejotacje czy akanie i ukanie.

Cytowane fragmenty dowodzą, że zarówno za pomocą języka, jak i treści Pulaki dystansują się od Polaków i polskiego języka literackiego. Odzwierciedla to poczucie świadomości językowej i odrębności Pulaków, jest demonstracją witalności i wysokiej wartości własnego dialektu. Już sam fakt, że tak liczna grupa (młodych) osób interesuje się polszczyzną regionalną i poświęca wolny czas na zastanawianie się nad kwestiami językowymi, napawa otuchą. Pulaki używają swojego języka ojczystego kreatywnie i bez ograniczeń w postaci reguł gramatycznych, świetnie się przy tym bawiąc. Pokazuje to, że polszczyzna na Litwie jest żywa i ciągle się rozwija. I nie tylko tak, jak chcieliby poloniści, ale również (a może nawet przede wszystkim) tak, jak korzystają z niej ludzie w życiu codziennym.

\section{BIBLIOGRAFIA}

Dawlewicz M., 2000, Słownictwo socjolektu młodzieży polskiego pochodzenia $w$ Wilnie (na podstawie badań ankietowych), Warszawa.

Duličen ko A., 2002, Vičsch, [w:] M. Okuka (red.), Enzyklopädie des europäischen Ostens, Klagenfurt(Celovec)-Wien-Ljubljana, s. 559-561.

Koniusz E., 2001, Polszczyzna z historycznej Litwy w „Słowniku gwar polskich” Jana Karłowicza, Kielce.

Kurzowa Z., 1993, Język polski Wileńszczyzny i kresów pótnocno-wschodnich XVI-XX w., Kraków.

Nagórko A., 2000, Kresy - ein typisches Beispiel für die Vermischung von Kulturen?, [w:] R. Marti (red.), Grenzkultur - Mischkultur?, Saarbrücken, s. 279-295.

Rieger J., Rutkowska K., Masojć I., 2006, Słownictwo polszczyzny gwarowej na Litwie, Warszawa.

Słownik języka polskiego, 1861, wyd. staraniem M. Orgelbranda, Wilno.

Tu rska H., 1948, Jeszcze w sprawie widzę pana starosty, „Język Polski”, XXVIII, 4, s. 105-111.

\section{WYKAZ ŹRÓDEŁ INTERNETOWYCH}

Blog Pulaki z Wilni: http://pulakizwilni.blogspot.de/2011/12/my-wilniuki.html, dostęp 15.08.2012. Kanał Pulaki z Wilni na YouTube: http://www.youtube.com/user/pulakizwilni, dostęp 20.08.2012. Kurier Wileński: http://kurierwilenski.lt, dostęp 17.12.2012.

Strona Pulaki z Wilni na Facebooku: http://www.facebook.com/pulakiziwlni?ref=ts\&fref=ts, dostęp 15.08.2012.

Poradnia Językowa PWN: http://poradnia.pwn.pl/, dostęp 31.07.2012. 
Portal Delfi w języku polskim: http://pl.delfi.lt/, dostęp 17.12.2012.

Zjazd Wilniuków: http://www.wilniuki.lt/, dostęp 31.7.2012.

\title{
YOUNG POLES IN LITHUANIA:
}

ABOUT PULAKI AND WILNIUKI

\begin{abstract}
The article analyses the blog and the corresponding Facebook group: Pulaki $z$ Wilni. The members of the group are mostly young people from Vilnius area in Lithuania, who consider themselves Poles. The group's main aim is to use their regional variety of Polish, also in a written form.

Since the members of the group also call themselves Wilniuki, the presentation of the Pulaki starts with this term and the way how Wilniuki characterize themselves. Furthermore, the article presents the self-description of the group Pulaki $z$ Wilni on Facebook and continues with an analysis of the users' language in numerous online discussions. We can note that the cited posts use much (self-)irony and over-use not only of regional attributes of Polish, but also Russian words and grammar. The users play with the language and communicate with a variety of Polish different from the generally recognised standard - they even sometimes create entirely novel words or expressions. The texts show a clear demarcation between Poland and the Polish language used there and the Polish language spoken by Wilniuki. They raise the value of regionalisms, but also of mixed languages and cultures. Yet, most of all it shows that many young Poles in Lithuania use Polish in a creative way, and that their language is a living language.
\end{abstract}

ПОЛЬСКАЯ МОЛОДЁЖЬ В ЛИТВЕ:

О ПУЛЯКАХ И ВИЛЬНЮКАХ

\section{PEЗЮME}

В статье рассматривается блог и соответствующая группа на Фейсбуке под названием Pulaki z Wilni. Участниками группы в основном являются молодые люди из Вильнюсского района Литвы, которые считают себя поляками. Основной целью группы является употребление регионального варианта польского языка, также в письменной форме.

Поскольку участники группы называют себя вильнюками (Wilniuki), презентация поляков (Pulaki) начинается именно с этого термина и того, как вильнюки себя описывают. Кроме того, статья представляет вопросы самоидентификации группы Pulaki z Wilni на Фейсбуке, анализ языка пользователей в разных 
обсуждениях онлайн. Легко заметить, что цитируемые посты полны (само-) иронии и чрезмерного употребления региональных элементов польского языка, а также русских заимствований и грамматики. Пользователи играют с польской речью и пишут - иногда даже создавая - свой вариант, который отличается от литературного польского языка. Тексты показывают чёткую разницу между разговорным польским языком в Польше и тем, который употребляют вильнюки. Рассматривается также вопрос ценности регионализмов и смешивания языков и культур. В то же время, показано, что многие молодые поляки из Литвы творчески употребляют польский язык и тем самым поддерживают его жизнеспособность.

Słowa kluczowe: mniejszość, język regionalny, Litwa, Polak, Facebook, młodzież.

Keywords: minority, regional language, Lithuania, Pole, social network (Facebook), youth.

Ключевые слова: национальное меньшинство, региональный язык, Литва, поляк, социальная сеть (Фейсбук), молодёжь. 